\title{
PEMBERDAYAAN PETERNAK SAPI DALAM UPAYA PENINGKATAN DERAJAT KESEHATAN MASYARAKAT DI DUKUH PAMOTAN DAN KRETEK BANGUNTAPAN
}

\author{
Oleh: \\ Musfirah, Ahmad Faizal Rangkuti, Khoiriyah Isni \\ Universitas Ahmad Dahlan Yogyakarta \\ E-mail: musfirah@ikm.uad.ac.id
}

\begin{abstract}
Ringkasan
Semakin berkembangnya usaha peternakan, limbah yang dihasilkan semakin meningkat. Seiring dengan pertumbuhan penduduk yang semakin meningkat maka meningkat pula kebutuhan akan pangan daging sapi. Dukuh Pamotan merupakan salah satu dukuh di Desa Jambidan dengan jumlah peternak sapi yang cukup banyak. Satu kelompok peternak sapi terdiri dari 10 orang peternak sapi dengan jumlah sapi sekitar 25 ekor. Tentunya jumlah ini akan menghasilkan limbah yang berupa kotoran ternak yang cukup banyak. Apabila tidak dikelola dengan baik, limbah kotoran ternak sapi ini dapat menjadi sumber masalah kesehatan di lingkungan Dukuh Pamotan. Hal tersebut didukung oleh letak peternakan yang sangat berdekatan dengan pemukiman warga padat penduduk. Metode yang digunakan dalam pemberdayaan masyarakat adalah penyuluhan dan praktek. Hasilnya menunjukkan bahwa kehadiran peserta selama kegiatan 93\%. Penilaian pre-post pengetahuan peserta menunjukkan peningkatan yang signifikan. Peserta terampil menangani limbah ternak dengan cara mengolah limbah ternak menjadi 3 (tiga) produk yaitu pupuk bokashi cair dan padat, serta pakan lele. Kesimpulannya, secara umum berjalan dengan sukses dan baik terbukti dari hasil penilaian oleh peserta berada pada kategori "Sangat Baik". Peserta memberikan apresiasi dan sambutan yang positif dengan adanya kegiatan pelatihan ini.
\end{abstract}

Kata kunci: Pemberdayaan, Peternak Sapi, Kesehatan Masyarakat

\section{Abstract}

As the livestock business grows, the waste generated increases. Along with the increasing population growth hence also increase the need for food of beef. Hamlet Pamotan is one of the dukuh in Jambidan Village with a large number of cattle ranchers. One group of cattle ranchers consists of 10 cattle ranchers with a total of 25 cows. Of course this amount will produce waste in the form of manure that quite a lot. If not properly managed, cattle dung waste can be a source of health problems in the neighborhood Pamotan Hamlet. This is supported by the location of farms that are very close to the densely populated residential population. The methods used in community empowerment are counseling and practice. The results show that attendance during the activities was $93 \%$. The pre-post assessment of participants' knowledge shows a significant improvement. Participants skillfully handling livestock waste by processing livestock waste into 3 (three) products namely liquid and solid bokashi fertilizer, and catfish feed. In conclusion, it is generally successful and well proven from the results of the assessment by the participants in the category of "Very Good". Participants give appreciation and positive response with the existence of this training activity.

Keywords: Empowerment, Cattle Breeders, Public Health 


\section{A. PENDAHULUAN}

Limbah ternak meliputi limbah padat dan limbah cair seperti feses, urine, sisa makanan, embrio, kulit telur, lemak, darah, bulu, kuku, tulang, tanduk, isi rumen, dan lainlain (Sihombing, 2000). Semakin berkembangnya usaha peternakan, limbah yang dihasilkan semakin meningkat. Seiring dengan pertumbuhan penduduk yang semakin meningkat maka meningkat pula kebutuhan akan pangan. Selain karbohidrat yang didapat dari hasil - hasil pertanian, untuk pertumbuhan manusia juga membutuhkan protein hewani yang didapat dari sector peternakan. Alhasil peternakan mulai berkembang dan tumbuh dari waktu kewaktu. Walaupun demikian populasi sapi perah maupun sapi potong mengalami peningkatan walaupun tidak terlalu signifikan. Secara Nasional menurut pendataan Sapi Potong, Sapi Perah dan Kerbau 2011, diperoleh angka 14,8 jt untuk Sapi Potong dan 597,1 ribu ekor untuk Sapi Perah. (Kementerian Pertanian, 2012).

Limbah padat yang tidak dikelola dengan maksimal dapat menurunkan kualitas lingkungan dan derajat kesehatan masyarakat. Hal tersebut konsisten dengan laporan Selin (2013) bahwa sebanyak 80 persen dari penyebaran penyakit di negara berkembang berhubungan dengan buruknya sistem pengelolaan limbah padat. Secara lokal, limbah padat yang tidak ditangani dengan baik berkontribusi terhadap estetika lingkungan, pencemaran udara, dan dampak kesehatan masyarakat seperti penyakit pernafasan, diare, dan demam berdarah (World Bank, 2012).

Menurut WHO, setiap tahunnya sekitar 2,2 juta orang di negara-negara berkembang terutama anak-anak meninggal dunia akibat berbagai penyakit yang disebabkan oleh kurangnya air minum yang aman, sanitasi dan hygiene yang buruk. Setiap saat, terdapat bukti bahwa pelayanan sanitasi yang memadai, persediaan air yang aman, sistem pembuangan limbah serta pendidikan hygiene dapat menekan tingkat kematian akibat diare sampai $65 \%$, serta penyakit-penyakit lainnya sebanyak $26 \%$. Berdasarkan paradigma sehat yang telah ditetapkan dalam visi Indonesia Sehat 2010, dimana ada 3 pilar yang perlu mendapat perhatian 5 khusus, yaitu lingkungan sehat, perilaku sehat serta pelayanan kesehatan yang bermutu, adil dan merata (Depkes RI, 2008).

Perilaku sehat bentuk konkritnya yaitu perilaku proaktif dalam memelihara dan meningkatkan kesehatan, mencegah risiko terjadinya penyakit, melindungi diri dari ancaman penyakit serta berpartisipasi aktif dalam upaya kesehatan. Mengingat dampak dari perilaku terhadap derajat kesehatan cukup besar (30-35\% terhadap derajat kesehatan), maka diperlukan berbagai upaya untuk mengubah perilaku yang tidak sehat menjadi sehat. Salah satunya melalui program Perilaku Hidup Bersih dan Sehat (PHBS).

Beberapa indikator sanitasi lingkungan yang direkomendasikan oleh Departemen Kesehatan Republik Indonesia antara lain persentase jumlah rumah sehat mencapai $80 \%$. Masalah kesehatan lingkungan misalnya perumahan, pembuangan feses manusia dan kotoran ternak, penyediaan air bersih, pembuangan sampah, dan pembuangan air limbah, berpengaruh terhadap kesehatan masyarakat terutama pada masalah kesehatan lingkungan rumah tangga. Secara keseluruhan kondisi kesehatan lingkungan di Indonesia masih sangat memprihatinkan (Soemirat, 2011).

Data Kementrian Kesehatan Republik Indonesia dalam Profil Kesehatan Indonesia menyebutkan bahwa penyakit demam berdarah dengue termasuk sepuluh terbesar penyakit pada pasien rawat inap rumah sakit di Indonesia pada tahun 2010. Demam Berdarah 
Diterbitkan oleh Lembaga Pengabdian kepada Masyarakat

Universitas Ahmad Dahlan Yogyakarta

Dengue menempati urutan kedua setelah penyakit diare dan gastroenteritis karena infeksi tertentu (Depkes RI, 2011). Berdasarkan data Kementerian Kesehatan Republik Indonesia dari tahun 2008 hingga tahun 2011, keseluruhan kabupaten/kota di Provinsi D.I Yogyakarta terjangkit demam berdarah dengue (Depkes RI, 2011). Penyakit Demam Berdarah Dengue (DBD) di Provinsi D.I.Yogyakarta pada tahun 2007 sebesar 2.578 kasus. Angka ini meningkat 27,06 \% dibanding pada tahun 2006 yaitu sebesar 1.887 kasus. Angka kesakitan tertinggi untuk penyakit DBD adalah di wilayah Kota Yogyakarta, disusul Kabupaten Sleman dan Kabupaten Bantul. Angka kesakitan DBD pada tahun 2007 sebesar 74,77\% (Depkes RI, 2008).

Dukuh Pamotan dan Dukuh Kretek yang berada di Desa Jambidan Kecamatan Banguntapan memiliki letak yang dikenal sebagai lembah di Kaki Bukit Imogiri dan Dlingo. Dukuh Pamotan merupakan salah satu dukuh di Desa Jambidan dengan jumlah peternak sapi yang cukup banyak. Satu kelompok peternak sapi terdiri dari 10 orang peternak sapi dengan jumlah sapi sekitar 25 ekor. Tentunya jumlah ini akan menghasilkan limbah yang berupa kotoran ternak yang cukup banyak. Apabila tidak dikelola dengan baik, limbah kotoran ternak sapi ini dapat menjadi sumber masalah kesehatan di Dukuh Pamotan.

Hal tersebut didukung oleh letak peternakan yang sangat berdekatan dengan pemukiman warga padat penduduk. Dengan demikian, pengelolan limbah ternak di Dukuh Pamotan masih sangat terbatas. Perlunya pemberdayaan peternak melalui pelatihan dan pendampingan kepada masyarakat Dukuh Pamotan pada umumnya dan kelompok peternak sapi pada khususnya terkait pengelolaan limbah kotoran ternak sapi. Sehingga hasil pengolahan limbah ternak tersebut tidak hanya bermanfaat untuk masyarakat namun juga dapat meminimalisir sumber masalah kesehatan berbasis lingkungan.

\section{B. METODE PELAKSANAAN}

Secara umum Program Pengabdian Masyarkat (PPM) yang telah dilaksanakan bertujuan untuk meningkatkan keterampilan dan partisipasi aktif masyarakat, khususnya kelompok peternak dalam mendorong kepedulian terhadap lingkungan untuk meminimalisir masalah kesehatan berbasis lingkungan akibat limbah kotoran ternak sapi dalam aktivitas peternakan sehari-hari. Bentuk kegiatan yang dilakukan dalam mencapai tujuan berupa penyuluhan. Hal ini dapat menambah sisi koginitif atau pengetahuan peternak tentang pengelolaan limbah ternak. Selain penyuluhan, peserta juga diberikan kesempatan untuk mempraktekkan secara langsung pengelolaan limbah ternak dengan memanfaatkan teknologi tepat guna. Ringkasan metode pelaksanaan beserta jam kerja pemberdayaan (JKP) tersaji pada tabel 1.

Tabel 1. Metode, Kegiatan, JKP dan keterlibatan mahasiswa

\begin{tabular}{|c|l|l|r|c|}
\hline No & Metode & Kegiatan & JKP & $\begin{array}{c}\text { Keterlibatan } \\
\text { Mahasiswa }\end{array}$ \\
\hline \multirow{2}{*}{1} & $\begin{array}{l}\text { Pendidikan } \\
\text { masyarakat }\end{array}$ & $\begin{array}{l}\text { Penyuluhan tentang } \\
\text { Pengantar: limbah ternak” }\end{array}$ & $1 \times 1$ jam & 3 Orang \\
\cline { 2 - 5 } & Penyuluhan & tentang & $1 \times 1 \mathrm{jam}$ & 3 Orang \\
\hline
\end{tabular}




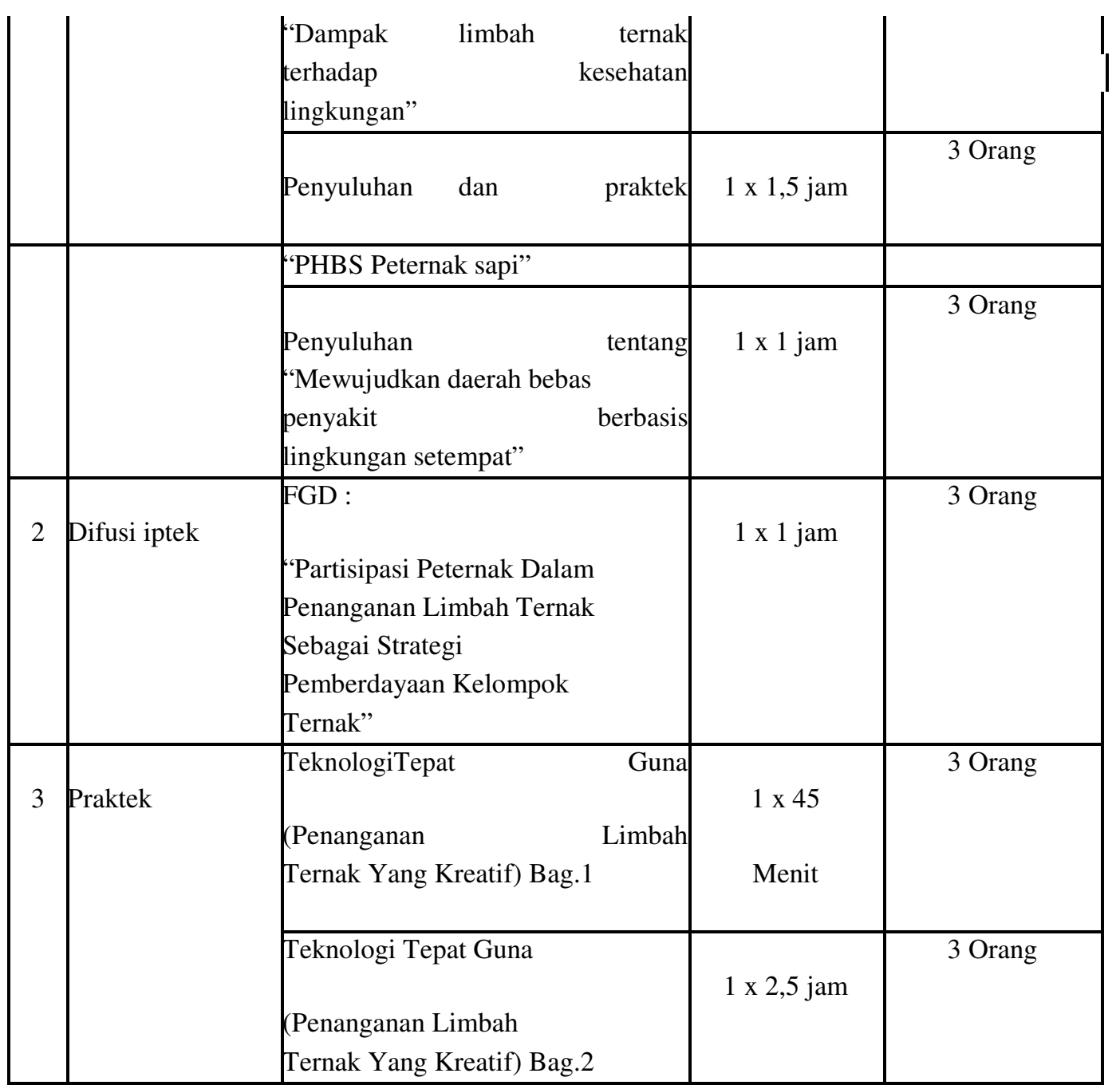

\section{HASIL, PEMBAHASAN DAN DAMPAK}

1. Profil Desa

Kecamatan Banguntapan merupakan salah satu kecamatan yang berada di di daerah Kabupaten Bantul dengan luas wilayah 2.848 Ha. Desa Jambidan sebagai salah satu desa yang berada di bagian selatan Kecamatan Banguntapan. Kondisi geografisnya sangat mendukung untuk pengembangan daerah pertanian, perkebunan dan juga peternakan. Sebagaimana sistem desa yang ada di beberapa daerah yang lain, Desa Jambidan juga masih di bagi menjadi beberapa pedukuhan dan RT yaitu Dukuh Ponegaran (9 RT), Bintaran (9 RT), Joho (9 RT), Dhuku (6 RT), Kretek (9 RT), Pamotan (5 RT), dan Combongan (7 RT). Jumlah Penduduk Desa Jambidan tahun 2015 tercatat sebanyak 10.444 jiwa. Mayoritas masyrakat bermata pencaharian sebagai petani, peternak dan buruh.

\section{Gambaran Pelaksanaan}

Pelaksanaan kegiatan PPM ini dilakukan selama 2 hari yaitu hari Rabu - Kamis tanggal 22-23 Februari 2017 pukul 10.00 sd 16.00 yang bertempat di Pendopo milik Bapak Edy Utama, Pugeran, RT 08, Jambidan, Banguntapan. Rangkaian kegiatan ini meliputi 
Diterbitkan oleh Lembaga Pengabdian kepada Masyarakat Universitas Ahmad Dahlan Yogyakarta

beberapa sesi yang diisi dengan materi baik yang sifatnya teori mapun praktek oleh 3 (tiga) orang pemateri sekaligus Tim PPM dan dibantu oleh tim teknis dari mahasiswa peminatan kesehatan lingkungan.

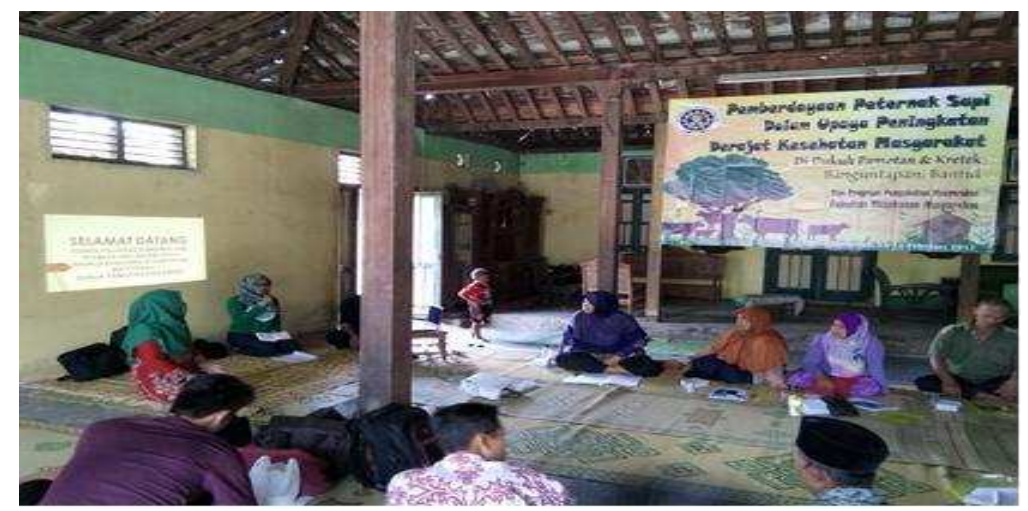

Gambar 1. Pembukaan Kegiatan

Pemberian teori bertujuan untuk memberikan pengetahuan mendasar kepada peternak sapi tentang limbah ternak, dampak limbah ternak bagi kesehatan lingkungan, edukasi PHBS (Perilaku Hidup Bersih dan Sehat) dalam menangani limbah ternak, perawatan ternak maupun perawatan kandang yang baik menurut perspektif lingkungan serta mengajak warga/peternak untuk mewujudkan daerah bebas penyakit berbasis lingkungan setempat. Selain itu materi ini bertujuan untuk memberikan gambaran tentang bagaimana menangani limbah ternak sapi agar tetap memperhatikan aspek kesehatan lingkungan dan bagaimana menghasilkan produk olahan yang bisa bernilai ekonomi yang tinggi melalui pemberdayaan kelompok peternak yang ada baik yang sudah aktif teregistrasi secara badan hukum maupun peternak yang masih individu. Materi praktik bertujuan untuk melatih peternak agar mampu melakukan penanganan limbah ternak dengan praktek langsung yang di bantu oleh tim PPM dan instruktur.

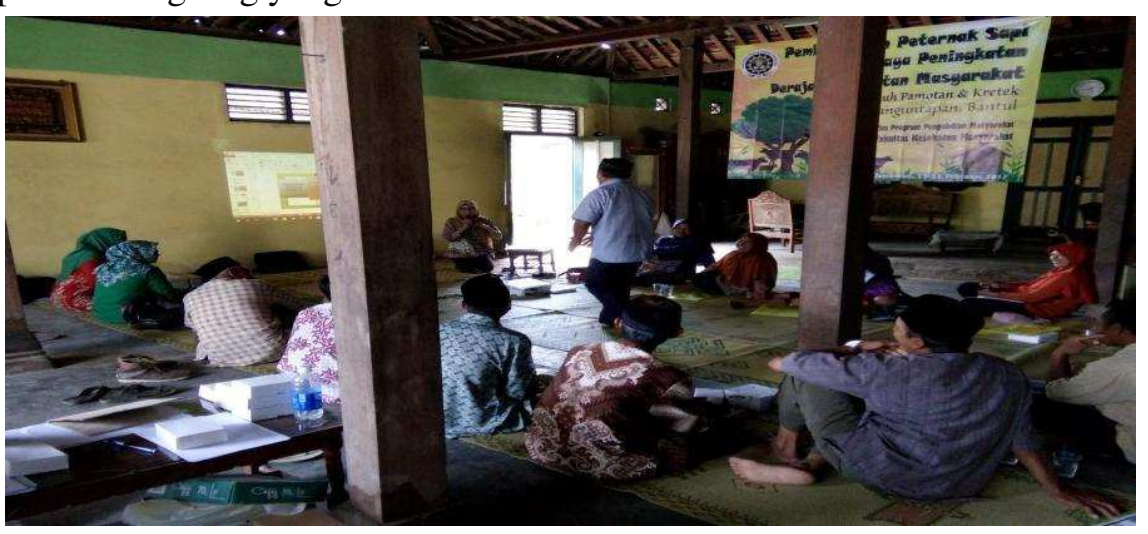

Gambar 2. Penyampaian Materi PHBS Peternak Sapi

Selain penyampaian dan praktik materi, peserta juga diberikan kesempatan untuk diskusi kelompok atau focus group discusion (FGD). Pada sesi FGD ini mereka berdiskusi tentang kondisi nyata limbah ternak setempat dan bagaimana cara menanganinya agar tidak berdampak buruk bagi kesehatan masyarakat. Hasil dari kegiatan FGD dapat dikategorikan 
cukup baik, hal ini dapat dilihat dari rata - rata kelompok sudah memiliki pemahaman yang bagus terkait analisis pemanfaatan limbah ternak di lingkungannya masing-masing. Pemahaman mereka ini tidak lepas dari materi yang sudah di sampaikan sebelumnya.

Pada sesi terakhir sebelum penutupan kegiatan, peserta di berikan kesempatan untuk menerapkan teknologi tepat guna dalam penanganan limbah ternak meliputi praktek pembuatan pupuk Bokashi Padat, pupuk Bokashi Cair, dan Pakan lele yang diikuti oleh hampir seluruh peserta. Antusiasme dan partisipasi aktif warga Dukuh Pamotan dan Kretek dalam kegiatan PPM ini sangat jelas terlihat. Hal ini dibuktikan dengan adanya keterlibatan warga selain peserta pelatihan yang ikut serta membantu dalam pembuatan pupuk dari limbah ternak sapi. Sebagai bahan penunjang peningkatan pengetahuan dan keterampilan peserta pelatihan, diberikan modul berjudul "Peternak Unggul: Terampil Menangani Limbah Ternak Sebagai Wujud Peduli Kesehatan Lingkungan" kepada peserta pelatihan.

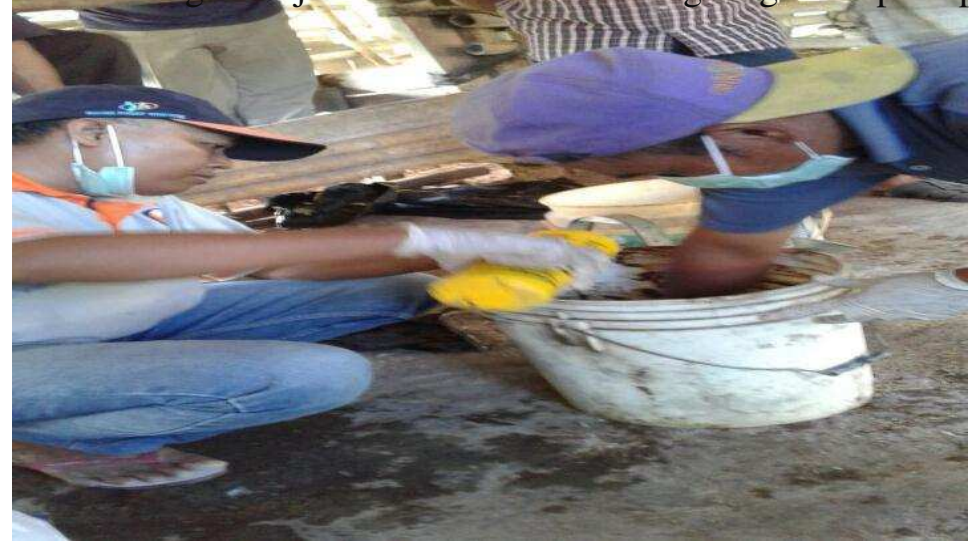

Gambar 3. Praktek Membuat Pakan lele dari Kotoran Ternak Sapi

Setiap dukuh menyambut positif kegiatan ini dan berharap agar program pendampingan bisa dilakukan pada semua dukuh yang ada di Desa Jambidan agar peternak bisa mengaplikasikan secara langsung penanganan limbah ternak yang tepat. Apabila peluang ini dimanfaatkan dengan baik, maka akan memperluas lapangan kerja sebab warga setempat dapat diberdayakan melalui program penanganan limbah ternak yang bisa dijadikan usaha bisnis menguntungkan.

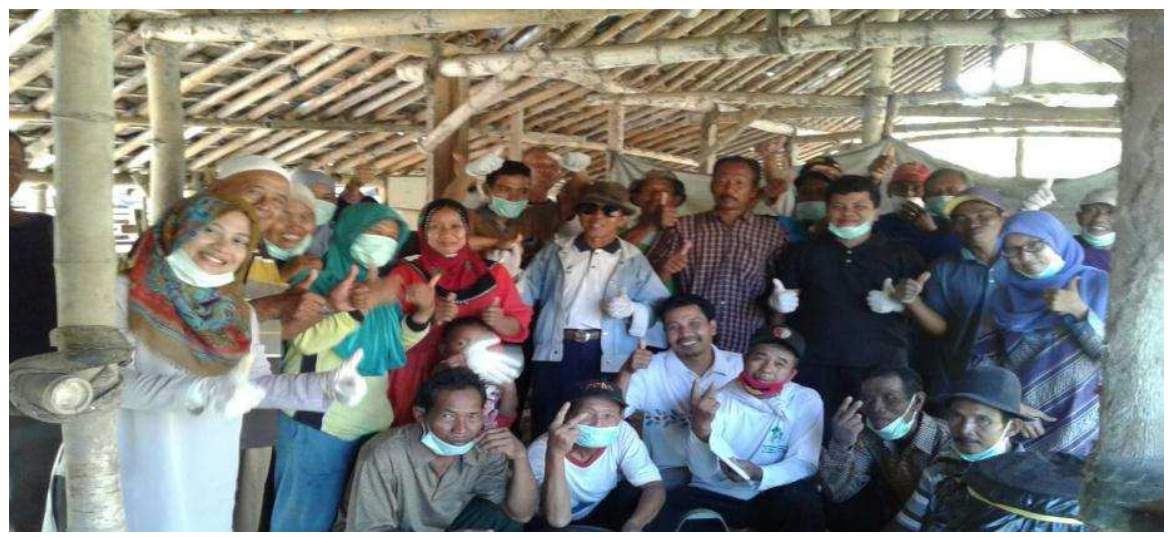

Gambar 4. Foto bersama setelah Praktik 
Diterbitkan oleh Lembaga Pengabdian kepada Masyarakat

Universitas Ahmad Dahlan Yogyakarta

Oleh karena itu, sebagai wujud komitmen kita dalam mewujudkan Kabupaten Bantul Sehat, diharapkan ada rencana tindak lanjut untuk melakukan perluasan daerah sasaran pembinaan kelompok peternak. Pihak Pimpinan Ranting Muhammadiyah (PRM) setempat akan terus meningkatkan kerjasama secara institusi/lembaga untuk membina peternak maupun warga sekitar peternakan yang ada untuk meminimalisir penyakit berbasis lingkungan dan berdampak ekonomi. Peran serta para stakeholder dan kalangan akademisi bidang kesehatan lingkungan sangat dibutuhkan dalam mengawal dan mendampingi kelompok peternak menuju Kabupaten Bantul Sehat.

\section{Evaluasi Proses dan Dampak}

Evaluasi proses dilakukan dengan tujuan untuk menilai proses selama kegiatan berlangsung. Dilakukan dengan cara memberikan kuesioner kepada para peserta pelatihan. Indikator penilaian evaluasi proses meliputi penilaian pre-post tingkat pengetahuan peserta tentang limbah ternak dan penaganannya, tema pelatihan, ketepatan waktu, suasana, sikap panitia, dan makanan. Hasil penilaian evaluasi proses disajikan pada Tabel 2 dan 3 berikut:

Tabel 2. Hasil Penilaian Pre-Post Tingkat Pengetahuan Peserta Pelatihan PPM Reguler Gazal 2016/2017

\begin{tabular}{lcc}
\multirow{2}{*}{ Indikator Penilaian } & \multicolumn{2}{c}{ Hasil Penilaian } \\
\cline { 2 - 3 } & Buruk & Baik \\
\hline Pre-Test Peserta & $63 \%$ & $37 \%$ \\
Post-test Peserta & $22 \%$ & $78 \%$ \\
\hline Total & & \\
\hline
\end{tabular}

Data Primer, 2017

Secara umum hasil penilaian pre-post test tingkat pengetahuan peserta menunjukkan peningkatan yang signifikan yaitu awalnya kategori "baik" hanya sebesar $37 \%$ lalu meningkat menjadi $78 \%$. Dengan demikian, pelatihan ini efektif meningkatkan wawasan dan pengetahuan peserta tentang limbah ternak dan cara penanganannya.

Evaluasi Pelaksanaan PPM berdasarkan Tabel 3 menunjukkan bahwa nilai ratarata hasil penilaian dalam kategori tertinggi yaitu "sangat baik" sebesar 71,40\%. 
Tabel 3. Evaluasi Pelaksanaan PPM Reguler Gazal 2016/2017

\section{Hasil Penilaian}

\begin{tabular}{llcc}
\cline { 3 - 3 } No & Indikator Penilaian & Cukup & Sangat \\
\cline { 3 - 4 } & & $33 \%$ & Baik \\
\hline 1 & Tema Pelatihan & $24 \%$ & $67 \%$ \\
2 & Ketepatan Waktu & $14 \%$ & $76 \%$ \\
3 & Suasana & $29 \%$ & $86 \%$ \\
4 & Sikap Panitia & $43 \%$ & $71 \%$ \\
5 & Makanan & & $57 \%$ \\
& & $\mathbf{1 4 3 \%}$ & $\mathbf{3 5 7 \%}$ \\
\hline & Total & $\mathbf{2 9 \%}$ & $\mathbf{7 1 . 4 0 \%}$ \\
\cline { 2 - 3 } & &
\end{tabular}

Data primer, 2017

Dengan demikian, dapat disimpulkan bahwa peserta menyambut positif dan antusias dalam mengikuti pelatihan tersebut agar menjadi peternak yang terampil dalam menangani limbah ternak. Kegiatan ini menurut peternak mampu meminimalisir dampak kesehatan lingkungan serta bisa dijadikan wadah untuk pengembangan diri agar menjadi peternak berdaya dan bisa mengedukasi warga lainnya agar bisa mengolah limbah ternak menjadi barang bernilai ekonomis seperti pupuk dan pakan tanpa mengabaikan aspek kesehatan lingkungan.

\section{KESIMPULAN}

1. Peserta pelatihan sangat antusias dalam mengikuti kegiatan pelatihan ini. Dibuktikan dengan kehadiran peserta selama kegiatan 93\%.

2. Peserta pelatihan terampil menangani limbah ternak dengan cara mengolah limbah ternak menjadi 3 (tiga) produk yaitu pupuk bokashi cair dan padat, serta pakan lele.

3. Hasil penilaian pre-post pengetahuan peserta menunjukkan peningkatan yang signifikan.

4. Hasil evaluasi proses pelaksanaan kegiatan PPM regular, secara umum berjalan dengan sukses dan baik terbukti dari hasil penilaian oleh peserta berada pada kategori "Sangat Baik". Peserta memberikan apresiasi dan sambutan yang positif dengan adanya kegiatan pelatihan ini. Peserta berharap adanya tindak lanjut dari kegiatan ini khususnya untuk para peternak dan warga sekitar di semua pedukuhan yang ada di Desa Jambidan. 
Diterbitkan oleh Lembaga Pengabdian kepada Masyarakat

Universitas Ahmad Dahlan Yogyakarta

\section{E. DAFTAR PUSTAKA}

Sihombing D T H. 2000. Teknik Pengelolaan Limbah Kegiatan/Usaha Peternakan. Pusat Penelitian Lingkungan Hidup Lembaga Penelitian, Institut Pertanian Bogor

Dikjend Peternakan \& Kesehatan Hewan. 2012. Statistik Peternakan dan Kesehatan Hewan. Kementerian Pertanian Republik Indonesia. Jakarta.

Selin, E. 2013. Solid waste management and health effects - A qualitative study on awareness of risks and environmentally significant behavior in Mutomo. Kenya: UMEA Universitet.

World Bank. 2012. What A Waste: A Global Review of Solid Waste Management. Washington, DC.

[Depkes RI]. Departemen Kesehatan Republik Indonesia 2008. Laporan Riset Kesehatan Dasar Tahun 2007, Jakarta.

[Depkes RI]. Departemen Kesehatan Republik Indonesia. 2011. Profil Kesehatan Indonesia. Jakarta.

Soemirat, Juli, 2011, Kesehatan Lingkungan, Edisi Revisi. Gadjah Mada University Press, Yogyakarta 
